\title{
Genotoxicity and mutagenicity of water contaminated with tannery effluents, as evaluated by the micronucleus test and comet assay using the fish Oreochromis niloticus and chromosome aberrations in onion root-tips
}

\author{
Silvia Tamie Matsumoto ${ }^{1}$, Mário Sérgio Mantovani ${ }^{2}$, Mirtis Irene Ariza Malaguttii ${ }^{3}$, Ana Lúcia Dias ${ }^{2}$, \\ Inês Cristina Fonseca ${ }^{4}$ and Maria Aparecida Marin-Morales ${ }^{5}$ \\ ${ }^{1}$ Universidade Federal do Espirito Santo, Departamento de Ciências Biológicas, Maruípe, Vitória, ES, \\ Brazil. \\ ${ }^{2}$ Universidade Estadual de Londrina, Departamento de Biologia Geral, Londrina, PR, Brazil. \\ ${ }^{3}$ Universidade Estadual Paulista 'Júlio de Mesquita Filho', Instituto de Geociências e Ciências Exatas, \\ Departamento de Petrologia e Metalogenia, Rio Claro, SP, Brazil. \\ ${ }^{4}$ Universidade Estadual de Londrina, Departamento de Agronomia, Londrina, PR, Brazil. \\ ${ }^{5}$ Universidade Estadual Paulista 'Júlio de Mesquita Filho', Instituto de Biociências, \\ Departamento de Biologia, Rio Claro, SP, Brazil.
}

\begin{abstract}
Cytotoxicity of metals is important because some metals are potential mutagens able to induce tumors in humans and experimental animals. Chromium can damage DNA in several ways, including DNA double strand breaks (DSBs) which generate chromosomal aberrations, micronucleus formation, sister chromatid exchange, formation of DNA adducts and alterations in DNA replication and transcription. In our study, water samples from three sites in the Córrego dos Bagres stream in the Franca municipality of the Brazilian state of São Paulo were subjected to the comet assay and micronucleus test using erythrocytes from the fish Oreochromis niloticus. Nuclear abnormalities of the erythrocytes included blebbed, notched and lobed nuclei, probably due to genotoxic chromium compounds. The greatest comet assay damage occurred with water from a chromium-containing tannery effluent discharge site, supporting the hypothesis that chromium residues can be genotoxic. The mutagenicity of the water samples was assessed using the onion root-tip cell assay, the most frequent chromosomal abnormalities observed being: c-metaphases, stick chromosome, chromosome breaks and losses, bridged anaphases, multipolar anaphases, and micronucleated and binucleated cells. Onion root-tip cell mutagenicity was highest for water samples containing the highest levels of chromium.
\end{abstract}

Key words: Allium cepa, chromium, chromosomes aberrations, comet assay, micronucleus, Oreochromis niloticus.

Received: May 2, 2005; Accepted: June 8, 2005.

\section{Introduction}

Pollution of water resources is a serious and growing problem but despite the existence of relevant legislation the pollution of the aquatic environment by toxic chemical pollutants continues to occur, with domestic and industrial effluents being the main sources responsible for the contamination of aquatic environments (Claxton et al., 1998; White and Rasmussen, 1998).

Chromium compounds are known to have toxic, genotoxic, mutagenic and carcinogenic effects on man and

Send correspondence to Maria Aparecida Marin-Morales. Universidade Estadual de São Paulo, Instituto de Biologia, Departamento de Biologia, Av. 24-A 1515, 13506-900 Rio Claro, SP, Brazil. E-mail: mamm@rc.unesp.br. animals (Von Burg and Liu, 1993; Stohs and Bagchi, 1995; Mount and Hockett, 2000), with both trivalent chromium III (Cr III) and hexavalent chromium VI (Cr VI) being biologically active but differing in their ability to cross biological membranes. Octahedral chromium III is potentially mutagenic but does not pose an immediate danger to cells because it is unable to cross cell membranes, although it may be environmentally transformed into tetrahedral hexavalent chromium VI (chromate) to which cell membranes are highly permeable (Leonard and Lauwerys, 1980; Beyersmann et al., 1994; Stohs and Bagchi, 1995; Singh et al., 1998; Matsumoto, 2003). According to Sugiyama (1992), hexavalent chromate enters cells via the surface transport system and inside the cell it is reduced to trivalent 
chromium which induces genotoxic effects in the cell (Bianchi et al., 1983). However, if trivalent chromium has access to the intracellular medium through processes such as pinocytosis and endocytosis or by the reduction of hexavalent chromium inside the cell it acts directly on DNA and causes more damage than when it continues in the chromate form (Matsumoto, 2003).

Several in vivo and in vitro studies have shown that chromium compounds damage DNA in a variety of ways, including DNA single and double-strand breaks (SDSBs) generating chromosomal aberrations, micronucleus formation, sister chromatid exchanges, formation of DNA adducts, and alteration in DNA replication and transcription (Zhitkovich et al., 1996; O'Brien et al., 2001; Matsumoto, 2003; Matsumoto and Marin-Morales, 2004).

Organisms used in mutagenesis testing should be selected using criteria that permit a realistic evaluation of the potential of a suspected mutagen to induce changes in genetic material such as structural and/or numerical modification of chromosomes resulting in chromosome aberrations. Aquatic organisms such as fish accumulate pollutants directly from contaminated water or indirectly through the ingestion of contaminated aquatic organisms. Thus, genotoxic pollutants may lead to the contamination not only of the aquatic organisms themselves but of the entire ecosystem and, finally, of humans through the food chain.

A variety of teleost fish, including larvae, have been used for the study of the mutagenic, clastogenic and teratogenic effects of environmental contaminants during the early stages of life. Metcalfe (1988) used the fish Oncorthychus mykiss and Oryzias latipes as test organisms for the study of carcinogenesis and model systems based on fish have become important for determining the distribution and toxic effects of aquatic contaminants, with in vivo techniques such as the micronucleus test performed in fish test systems having been shown to be efficient not only for assessing genotoxic potential but also for water quality monitoring (Al-Sabti and Metcalfe, 1995; and Dashwood and Bariley, 1998).

The analysis of the frequency of micronuclei during interphase is a rapid and easy to conduct technique. Teleost erythrocytes possess a nucleus and are a good tool for the detection of clastogenic substances in water, the fish erythrocyte micronucleus test having been used as an initial step in evaluating clastogenic potential. Several studies have shown a high incidence of micronuclei in fish peripheral erythrocytes after exposure to different pollutants under both field and laboratory conditions (Al-Sabti, 1986; Metcalfe, 1988; Hose et al., 1987; Minissi et al., 1996).

Al-Sabti (1994) used the micronucleus test to determined the cytological effects of hexavalent and trivalent chromium in erythrocytes of Carassus auratus gibelio fish exposed to sub-lethal chromium concentrations in the laboratory and fish collected from chromium-contaminated rivers showing a significant frequency of micronuclei when compared to negative controls and thus demonstrating the true genotoxic effect of chromium.

Nuclear abnormalities are frequently observed in fish erythrocytes, with Carrasco et al. (1990) having described such abnormal nuclei as being blebbed, notched or lobed. Other investigators have also reported nuclear abnormalities but simply classified them as 'genotoxic damage' (Bombail et al., 2001; Pachecco and Santos, 1998; Ayylon and Garcia-Vazquez, 2000). Eiras (1990) identified nuclear abnormalities in fish with folic acid deficiency or which had been affected by viral necrosis, as well as in specimens exposed to chlorine and cadmium.

The single cell gel electrophoresis (SCGE) assay, commonly called the comet assay, is a genotoxicity test able to detect DNA damage induced by alkylating, intercalating and oxidizing agents (Tice et al., 2000; KoszVnenchak and Rokosz, 1997). The comet assay has been used as an important tool for monitoring genotoxicity in aquatic environments. For this purpose, fish are used as a test organism in which it is possible to detect DNA damage induced by direct mutagens and pro-mutagens in both fresh and salt water (Mitchelmore and Chipman, 1998; Lemos et $a l ., 2005)$. This technique has also been employed in the determination of the genotoxic potential of water resources such as rivers and lakes.

According to Matsumoto et al. $(2003,2005)$ the comet test is sensitive enough to be used for the environmental monitoring of waters and is suitable for assessing the quality of water contaminated with effluents containing chromium residues, these authors having used the comet assay to detect genotoxicity effects caused by chromium concentrations as low as $0.01 \mathrm{mgL}^{-1}$ which is significantly less than the $0.05 \mathrm{mgL}^{-1}$ currently accepted as the international standard for chromium (CETESB, 1995).

An efficient test organism for the assessment of chromosomal aberrations should have chromosomes which are easy to analyze in terms of size, morphology and number. The higher plants Allium cepa (onion), Tradescantia paludosa and Vicia faba have relatively large monocentric chromosomes in reduced numbers and are accepted as suitable test organisms for the study of environmental mutagenesis (Rank and Nielsen, 1998; Grover and Kaur, 1999; Kong and Ma, 1999; Moraes and Jordão, 2001; Patra and Sharma, 2002).

The clastogenic and aneugenic effect of atmospheric, water and soil pollutants have been demonstrated by several authors using the micronucleus assay in $A$. cepa and $V$. faba root tip cells (Grover and Kaur, 1999; Sudhakar et al., 2001; and Patra and Sharma, 2002), these authors having reported that the chromosomal changes most frequently observed were c-metaphases, stick chromosomes and breaks, bridges, laggards, binucleate cells and micronucleated cells.

Contamination of the environment by heavy metals has been increasing every year (Majer et al., 2002) and the 
analysis of the cytotoxic effects of such metals has received special attention due to the fact that they are potentially mutagenic and induce the formation of tumors in experimental organisms and humans exposed to them (GarciaRodríguez et al., 2001).

Sahi et al. (1998) used $A$. cepa test systems to assess the effects of chromium contamination on the waters of an Indian river and showed that at sites where chromium concentrations were high there was a reduction in mitotic index and an increase in the rate of mitotic abnormalities, thus confirming the cytotoxic and genotoxic effect of chromium.

In the municipality of Franca in the Brazilian state of São Paulo there are several leather tanneries which use trivalent chromium salts for tanning and which discharge effluents into the Córrego dos Bagres stream. The study described in this paper used the erythrocyte comet assay and micronucleus test in the fish Oreochromis niloticus and the cellular cycle of onion root tip cells to investigate three sites along the Córrego dos Bagres stream for the genotoxic and mutagenic potential of tannery effluents which may be contaminated with chromium.

\section{Material and Methods}

\section{Sampling sites and chemical analyses}

The Corrego dos Bagres stream in the Franca municipality in the Brazilian state of São Paulo is a small stream which receives tannery effluents. We collected water samples from this stream during spring, summer, autumn, and winter of 2001 and 2002 at three locations, one being 200 meters upstream of the tannery effluent discharge site, one at the tannery effluent discharge site and another 500 meters downstream of the effluent discharge site (Figure 1). In this context 'upstream' means in the higher part of the stream nearer the source of the stream and against the flow of the current while 'downstream' means nearer the mouth of the river and in the direction of the water flow.

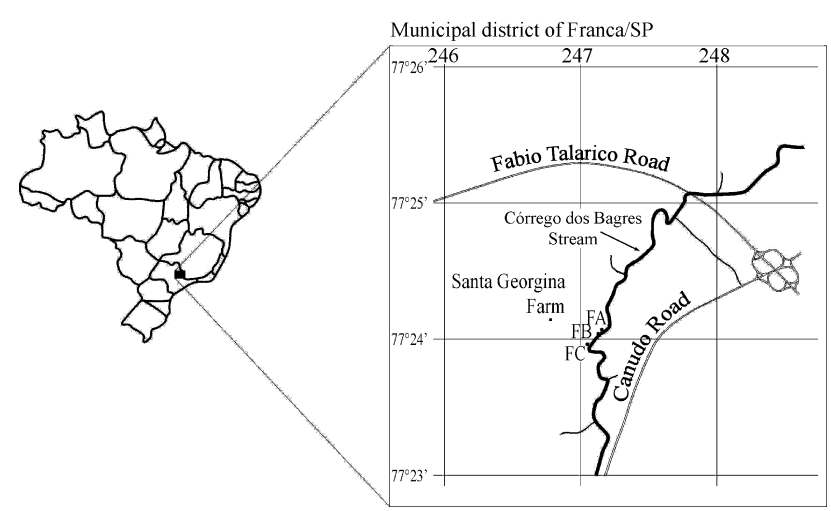

Figure 1 - Geographical localization of the collected site along the "Córrego dos Bagres" stream. FA = upstream of the effluent discharge site; $\mathrm{FB}=$ effluent discharge site, $\mathrm{FC}=$ downstream of the effluent discharge site.
Chemical analysis of the waters was carried out using standard methods (Franson, 1995). For cation determination, the samples were first acidified with $\mathrm{HNO}_{3}(\mathrm{pH} 1)$ and the cations sequentially analyzed by inductively coupled plasma atomic emission spectrometry (ICP-AES) with ultrasonic nebulization. The following elements were determined: calcium, magnesium, strontium, silicon, iron, manganese, aluminum, zinc, chromium, cobalt, nickel, lead, cadmium, phosphorus, copper, and barium. The standard solutions $\left(1 \mathrm{~g} \mathrm{~L}^{-1}\right)$ used to construct the calibration curves for the elements were made up in $0.1 \% \mathrm{HNO}_{3}$ and appropriate dilutions made in titrisol (Merck).

\section{Micronucleus test and comet assay using the fish Oreochromis niloticus}

The water samples colleted in summer of 2001 from the three sites were placed in individual aquaria and diluted 1:1 (v/v) with well-water from State University of Londrina, and then aerated continuously for three days, after which 6 adult of Oreochromis niloticus with $10 \mathrm{~cm}$ long health were added to each aquarium and left for $72 \mathrm{~h}$. The fish were kindly provided by the Fish Farm of the State University of Londrina, Paraná, Brazil. Control fish were placed in aquarium containing the same volume of wellwater.

For the micronucleus test $O$. niloticus blood samples were obtained by tail puncture using heparinized syringes. Smears were prepared on slides, with 6 slides being prepared (one from each fish) for each water sample. After 24 $\mathrm{h}$, the material was fixed in absolute methanol for $10 \mathrm{~min}$ and stained with 5\% Giemsa for $20 \mathrm{~min}$. The number of normal erythrocytes without micronuclei and the number of damaged cells with micronuclei were determined by analysis of 2000 cells per fish (Huber 1992), the KruskalWallis test being used to compare the results for fish exposed to collection site water with those for control fish exposed to well-water only.

For the comet assay blood was obtained from the fish as described above and $10-\mu \mathrm{L}$ aliquots diluted in $1000 \mu \mathrm{L}$ of fetal bovine serum8. Microscope slides were coated with $120 \mu \mathrm{L}$ of $0.5 \%(\mathrm{w} / \mathrm{v})$ low melting point agarose at $37^{\circ} \mathrm{C}$ containing $10 \mu \mathrm{L}$ of the diluted blood and the slides placed in lysis buffer (10 mM Tris, $\sim 8 \mathrm{~g}$ of $\mathrm{NaOH}$ and $10 \mathrm{~mL}$ of $1 \%$ $(\mathrm{w} / \mathrm{v})$ sodium lauryl sarcosinate solution plus $1 \mathrm{~mL}$ of Triton $\mathrm{X}-100,10 \mathrm{~mL}$ of DMSO and $89 \mathrm{~mL}$ of $\mathrm{pH} 10$ lysis solution containing $2.5 \mathrm{M} \mathrm{NaCl}, 100 \mathrm{mM}$ EDTA, $10 \mathrm{mM}$ Tris and $\sim 8 \mathrm{~g}$ of $\mathrm{NaOH}$ ) in a refrigerator for $1 \mathrm{~h}$. After lysis, the slides were incubated in $300 \mathrm{mM} \mathrm{NaOH}+1 \mathrm{mM}$ EDTA buffer $(\mathrm{pH}>13)$ for $20 \mathrm{~min}$ to denature the DNA and then submitted to electrophoresis at $25 \mathrm{~V}$ and $300 \mathrm{~mA}$ for $20 \mathrm{~min}$. The slides were then neutralized with $0.4 \mathrm{M}$ Tris for $15 \mathrm{~min}$ and fixed in ethanol for $10 \mathrm{~min}$. For each fish 100 nuclei were analyzed per blood sample. The slides were stained with ethidium bromide $\left(0.02 \mathrm{mg} \mathrm{mL}^{-1}\right)$ and analyzed under a Nikon fluorescence microscope equipped 
with a B-3 ${ }^{\mathrm{A}}$ filter (excitation: $\lambda=420-490 \mathrm{~nm}$, emission barrier: $\lambda=520 \mathrm{~nm}$ ) and a $40 \mathrm{x}$ objective lens. The nuclei were visually classified according to fragment migration as undamaged (class 0), slightly damaged (class 1), more damaged (class 2 ) and highly damaged (class 3 ). The $\chi^{2}$ test was used to compare the total number of altered nuclei from fish exposed to site water with control fish exposed to well-water only.

\section{Onion root-tip mutagenicity test}

For this test onion (A. cepa variety Periform Baia) seeds were germinated in Petri plates containing water from the collection sites, pollutant-free Milli-Q water being the negative control (NC) and an aqueous solution of $0.089 \mathrm{mg} \mathrm{L}^{-1}$ trivalent chromium the positive control (PC). Two types of treatments were applied, a continuous treatment in which the seeds were soaked and germination in the water from the collection sites until the radicals reached $2 \mathrm{~cm}$ in lenght and a discontinuous treatment in which the seeds were first soaked in Milli-Q water until the radicals reached $2 \mathrm{~cm}$ in length and then transferred to a Petri plates containing water from the collection sites and were left for $20 \mathrm{~h}$ (acute treatment) after which some of the rooted seeds were collected at random and assessed, the remaining roots being left under the same conditions until $72 \mathrm{~h}$ (chronic treatment) before being collected. For the samples taken in 2002, after chronic treatment some roots were transferred to plates containing Milli-Q water and left to recover for $48 \mathrm{~h}$ before being assessed. After treatment roots were fixed in 3:1 (v/v) ethanol/glacial acetic acid (Carnoy solution) for $24 \mathrm{~h}$, carefully squashed and hydrolyzed with $1 \mathrm{~N} \mathrm{HCl}$ at $60{ }^{\circ} \mathrm{C}$ for $8 \mathrm{~min}$, washed with distilled water and Schiff stained for $2 \mathrm{~h}$ in the dark. All cells with alterations were counted and the most representative ones for each abnormality were photographed. For the mutagenicity assessment dividing cells with irregular anaphases (i.e. disorganized structure, lag chromosomes or multipolar anaphases), cells with stick chromosomes, micronuclei, and binucleate and/or multinucleate cells were recorded. These data were analyzed using the Kruskal-Wallis test.

\section{Results and Discussion}

The $O$. niloticus micronucleus test and the comet assay showed that the water collected at the three sites on the Córrego dos Brages stream was significantly genotoxic as compared to the well-water used as the negative control.

Water from the effluent discharge site produced the highest nuclear abnormality frequency $(2.53 \%)$ and micronuclei frequency $(0.45 \%)$, with the data showing that, as expected, water from the effluent discharge site was more genotoxic due to the presence of tannery effluent which resulted in a higher rate of abnormalities (Table 1, Figures 2 and 3 ). The nuclear abnormality and micronuclei data suggest that concentrations lower than $0,05 \mathrm{mgL}^{-1}$ induce ef- fects genotoxic in the exposed organisms, supported by the chemical analysis of the water collected from this site (Table 3). Our results agree with those reported by Von Burg and Liu (1993), Blasiak and Kowalik (2000) and Matsumoto et al. (2003), who proposed that chromium exerts a genotoxic effect on animals due to its potential to cause various forms of DNA damage

The micronuclei and nuclear abnormality data showed that water from the upstream and downstream sites were less genotoxic than water from the effluent discharge site. At the upstream site, the nuclear abnormality frequency was $1.77 \%$ and the micronuclei frequency $0.20 \%$, although this micronuclei frequency was not significantly different to that found for the well-water used as the negative control. At the downstream site, the nuclear abnormality frequency was $2.12 \%$ and micronuclei frequency $0.26 \%$ (Table 1 and Figures 2 and 3). Compared to water from the upstream site and the negative control water, the micronuclei frequency was significantly higher for water from the effluent discharge and downstream sites, demonstrating that upstream of the discharge site the genotoxic effect was smaller than at the effluent discharge site and the downstream site. These data support the view of Matsumoto et al. (2003) that chromium-containing tannery residues in the Franca region represents a genotoxic pollution hazard.

The erythrocyte nuclear abnormalities (Figure 3) were classified as blebbed, notched and lobed (Carrasco et al. 1990; Ayylon and Garcia-Vazquez, 2000; Çavas and Ergene-Gözükara, 2003). Water from the effluent discharge and downstream sites produced a significantly higher frequency of nuclear abnormalities compared to the negative control well-water, indicating that these abnormalities are the consequence of the genotoxic effect of chromium

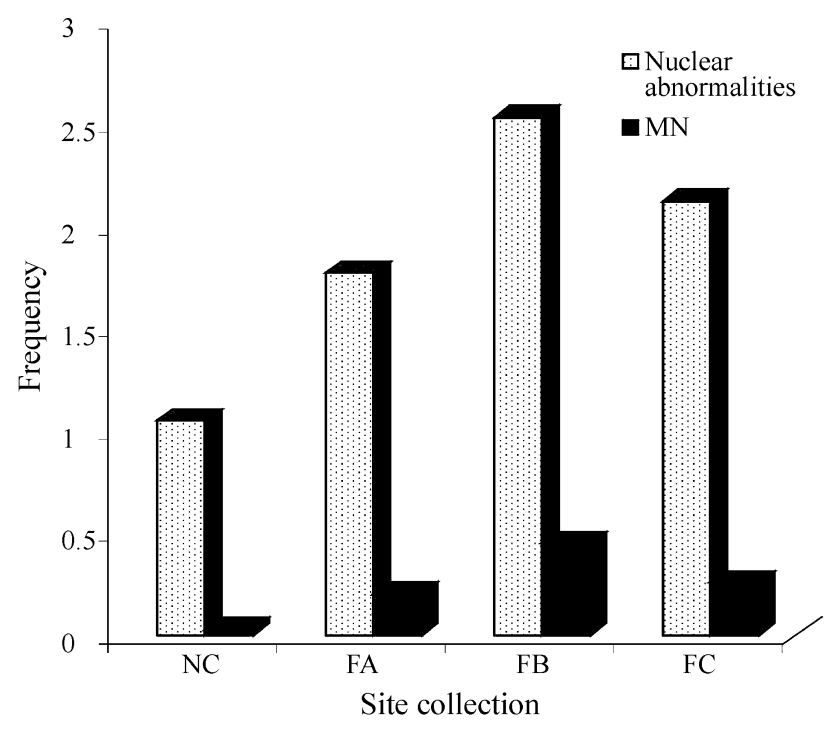

Figure 2 - Frequency of erythrocytes (Oreochromis niloticus) with a micronucleus and nuclear abnormalities. FA = upstream of the effluent discharge site; $\mathrm{FB}=$ effluent discharge site, $\mathrm{FC}=$ downstream of the effluent discharge site. 
residues present in the tannery waste water discharged into the stream.

The comet assay has been shown to be efficient in the detection of DNA damage provoked by genotoxic agents present in aquatic environments, Mitchelmore and
Chipman (1998) having stated that the comet assay using fish as the test organism is an effective technique for monitoring the genotoxic potential of aquatic environments.

The damage detected by the comet assay for water from the upstream site was not significantly different to that

Table 1 - Changes observed in erythrocytes of six Oreochromis niloticus fish placed for $72 \mathrm{~h}$ in a 1:1 (v/v) mixture of well-water and water collected at several sites on the Córrego dos Bagres stream. The stream water was collected in summer of 2001 from a tannery industry chromium-containing effluent discharge site and at sites upstream and downstream. Well-water was also the negative control.

\begin{tabular}{|c|c|c|c|c|c|c|c|c|c|}
\hline \multirow{3}{*}{ Sample site } & \multicolumn{3}{|c|}{$\begin{array}{l}\text { Micronucleus test }(2000 \text { cells analyzed } \\
\text { for each fish, total }=6000)\end{array}$} & \multicolumn{6}{|c|}{ Comet assay (100 cells analyzed for each fish, total $=600)$} \\
\hline & \multirow[t]{2}{*}{$\mathrm{NC}$} & \multirow[t]{2}{*}{ CNA } & \multirow[t]{2}{*}{$\mathrm{MC}$} & \multirow[t]{2}{*}{ TCA } & \multicolumn{4}{|c|}{ Comet class $^{1}$} & \multirow[t]{2}{*}{$\mathrm{CS}$} \\
\hline & & & & & 0 & 1 & 2 & 3 & \\
\hline \multicolumn{10}{|l|}{ Negative control } \\
\hline Fish 1 & 1980 & 20 & 0 & 26 & 74 & 22 & 4 & 0 & 30 \\
\hline Fish 2 & 1983 & 15 & 2 & 21 & 79 & 17 & 4 & 0 & 25 \\
\hline Fish 3 & 1976 & 23 & 1 & 20 & 80 & 19 & 1 & 0 & 21 \\
\hline Fish 4 & 1984 & 15 & 1 & 18 & 82 & 14 & 3 & 1 & 23 \\
\hline Fish 5 & 1991 & 9 & 0 & 77 & 23 & 57 & 16 & 4 & 101 \\
\hline Fish 6 & 1956 & 44 & 0 & 19 & 81 & 14 & 5 & 0 & 24 \\
\hline Total & 11870 & 126 & 4 & 181 & 419 & 143 & 33 & 5 & $x=37.33$ \\
\hline Frequency $(\%)$ & 98.92 & 1.05 & 0.03 & - & - & - & - & - & - \\
\hline \multicolumn{10}{|l|}{ Upstream site } \\
\hline Fish 1 & 1956 & 38 & 6 & 19 & 81 & 10 & 8 & 1 & 29 \\
\hline Fish 2 & 1922 & 71 & 7 & 15 & 85 & 8 & 4 & 3 & 25 \\
\hline Fish 3 & 1991 & 8 & 1 & 18 & 82 & 17 & 1 & 0 & 19 \\
\hline Fish 4 & 1985 & 11 & 4 & 42 & 59 & 29 & 9 & 3 & 56 \\
\hline Fish 5 & 1946 & 51 & 3 & 47 & 53 & 32 & 9 & 6 & 68 \\
\hline Fish 6 & 1964 & 33 & 3 & 54 & 46 & 42 & 9 & 3 & 69 \\
\hline Total & 11764 & 212 & 24 & 195 & 406 & 138 & 40 & 16 & $x=44.33$ \\
\hline Frequency $(\%)$ & 98.03 & 1.77 & 0.2 & - & - & - & - & - & - \\
\hline \multicolumn{10}{|c|}{ Effluent discharge site } \\
\hline Fish 1 & 1956 & 36 & 8 & 41 & 59 & 34 & 6 & 1 & 49 \\
\hline Fish 2 & 1913 & 74 & 13 & 21 & 79 & 13 & 4 & 4 & 33 \\
\hline Fish 3 & 1938 & 53 & 9 & 59 & 41 & 48 & 7 & 4 & 74 \\
\hline Fish 4 & 1966 & 30 & 3 & 39 & 61 & 30 & 4 & 5 & 53 \\
\hline Fish 5 & 1935 & 56 & 9 & 57 & 43 & 41 & 10 & 6 & 79 \\
\hline Fish 6 & 1937 & 55 & 12 & 76 & 24 & 34 & 27 & 15 & 133 \\
\hline Total & 11645 & 304 & 54 & $293^{*, * *}$ & 307 & 200 & 58 & 35 & $x=70.17$ \\
\hline Frequency $(\%)$ & 97.02 & 2.53 & 0.45 & - & - & - & - & - & - \\
\hline \multicolumn{10}{|l|}{ Downstream site } \\
\hline Fish 1 & 1959 & 35 & 6 & 47 & 53 & 35 & 7 & 5 & 64 \\
\hline Fish 2 & 1947 & 48 & 5 & 53 & 47 & 31 & 15 & 7 & 82 \\
\hline Fish 3 & 1956 & 39 & 5 & 53 & 47 & 37 & 8 & 8 & 77 \\
\hline Fish 4 & 1951 & 42 & 7 & 48 & 52 & 21 & 15 & 12 & 87 \\
\hline Fish 5 & 1946 & 50 & 4 & 23 & 77 & 15 & 3 & 5 & 36 \\
\hline Fish 6 & 1955 & 40 & 5 & 20 & 80 & 14 & 6 & 0 & 26 \\
\hline Total & 11714 & 254 & 32 & $244^{*, * * *}$ & 356 & 152 & 54 & 37 & $x=62.0$ \\
\hline Frequency (\%) & 97.62 & 2.12 & 0.26 & - & - & - & - & - & - \\
\hline
\end{tabular}

${ }^{1}$ Class $0=$ undamaged, $1=$ slightly damaged, $2=$ more damaged and $3=$ highly damaged. * significantly different in relation to the negative control site by the mean rank $\chi^{2}$ test at $\mathrm{p}=0.05$. $* *$ significantly different in relation to the upstream site by the the mean rank $\chi^{2}$ test at $\mathrm{p}=0.05$. $* * *$ significantly different in relation to the effluent discharge site by the the mean rank $\chi^{2}$ test at $\mathrm{p}=0.05$. NC: Normal cells. CNA: Cells with nuclear abnormalities. MC: Micronucleated cells. TCA: Total cells analyzed with comet. CS: Comet scores $(\mathrm{x}=$ mean score $)$. 


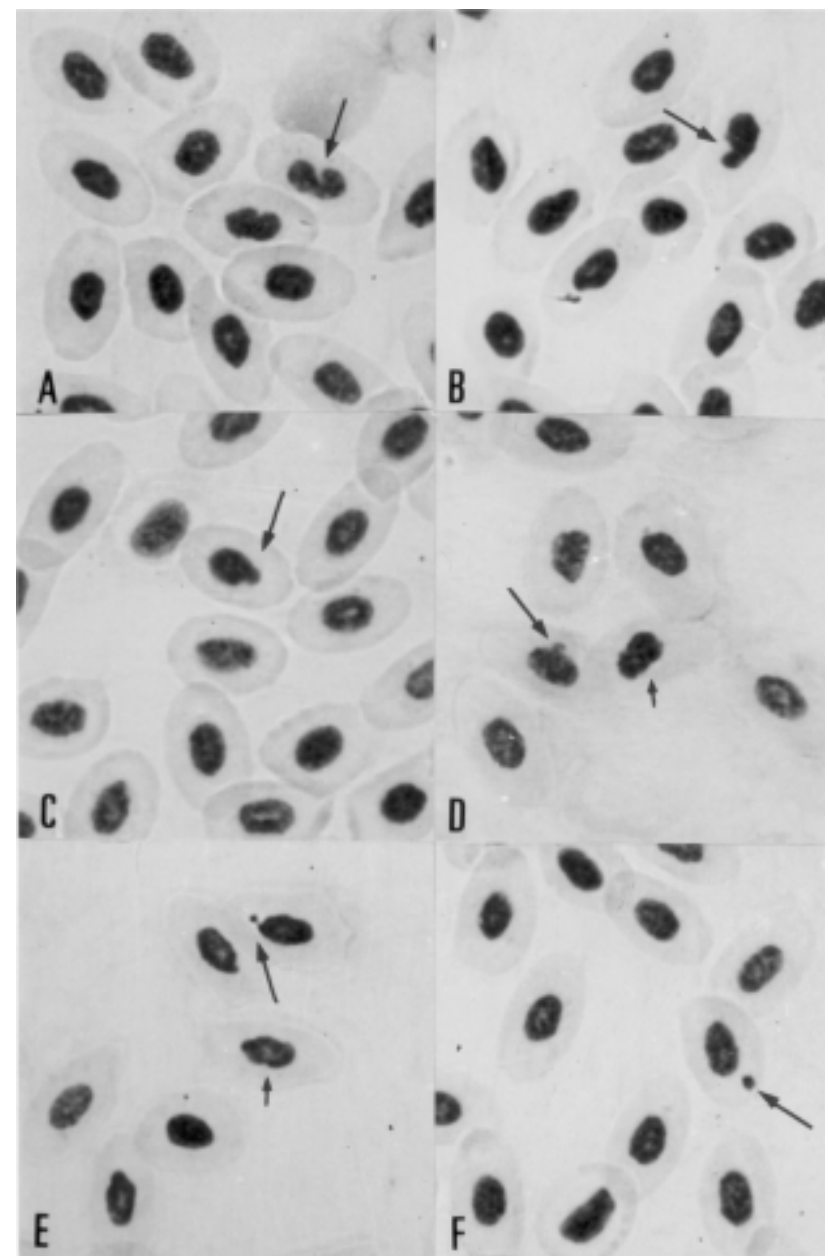

Figure 3 - Erytrocytes (Oreochromis niloticus) with a micronucleus and nuclear abnormalities: A and B-Notched nuclei; C-Lobed nuclei; D-Lobed nuclei (large arrow) and blebbed nuclei (small arrow); E-Broken eggs (large arrow) and blebbed nuclei (small arrow); F-Micronucleus.

detected for the negative control (Table 1 and Figure 4), a finding explainable by the fact that the upstream site receives little or no tannery effluent. The comet assay results revealed significant genotoxic effects for water from the effluent discharge and downstream sites compared to the negative control well-water (Table 1, Figure 4), with the highest damage frequency occurring with water from effluent discharge site, confirming the genotoxic effect of the chromium residues present at the tannery effluent disposal site. These results support those of Matsumoto et al. (2003) who used the comet assay and $\mathrm{CHO}-\mathrm{K} 1$ cell cultures to de- tect genotoxicity caused by water contaminated with tannery effluent containing a chromium concentration lower than that permitted by the legislation of the State of São Paulo (0.01 $\left.\mathrm{mg} \mathrm{L}^{-1}\right)$.

To estimate the mutagenic effect of the water samples, we calculated the ratio of aberrant to dividing onion cells and found that, with one exception, for all the samples collected during the dry and rainy seasons of 2001 and 2002 the aberrant onion cell rate was higher than that recorded for the negative control (Tables 2), the exception being water from the upstream site collected during the dry period of 2002 and used in the continuous exposure experiments.

For water samples collected during the dry period (Auttumn and Winter) of 2001, mutagenic and clastogenic effects were recorded for water from the effluent discharge site continuous exposure experiments and the upstream and effluent discharge sites $20 \mathrm{~h}$ discontinuous exposure experiments, while for water collected during the rainy season (Spring and Summer) of the same year such effects were observed only for the effluent discharge site $72 \mathrm{~h}$ chronic discontinuous exposure experiments. Table 3 shows that during 2001 the chromium concentration at the effluent discharge site was higher than the maximum concentration $(0.05 \mathrm{mg} / \mathrm{L})$ permitted by the 1995 legislation of the State of São Paulo. These results support the hypothesis that chromium is the contaminant present in the water samples of the Bagres Stream and is responsible for the clastogenic action on onion root-tip cells.

For the water samples collected in 2002 both during the dry and rainy seasons, the frequency of aberrant cells was high for water collected from the effluent discharge and downstream sites (Table 2), again supporting the hypothesis that the observed mutagenicity was due to the tannery effluent chromium-content (Table 3). The most frequent aberrations observed were c-metaphases, stick chromosomes, anaphase irregularities (dots and multipolarity), chromosome breaks and cells with micronuclei or binucleate (Table 2, Figure 5, 6 and 7). Some cells showed the loss of whole chromosomes, which persisted up to telophase (Figure 6), such losses probably resulting in micronucleated interphase cells. These results agree with those obtained by Sudhakar et al. (1998), who reported micronucleus induction involving the mitotic spindle and consequent production of laggard chromosomes during anaphase and the loss of a complete chromosome. In our
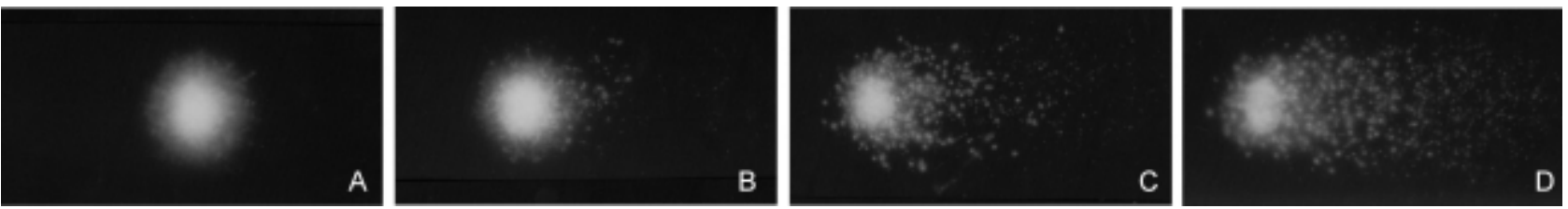

Figure 4 - Results of the comet assay performed with Oreochromis niloticus erythrocytes. A- Class 0 (cell without damage); B-Class 1 (small damage); C- Class 2 (medium damage) and D- Class 3 (large damage). 


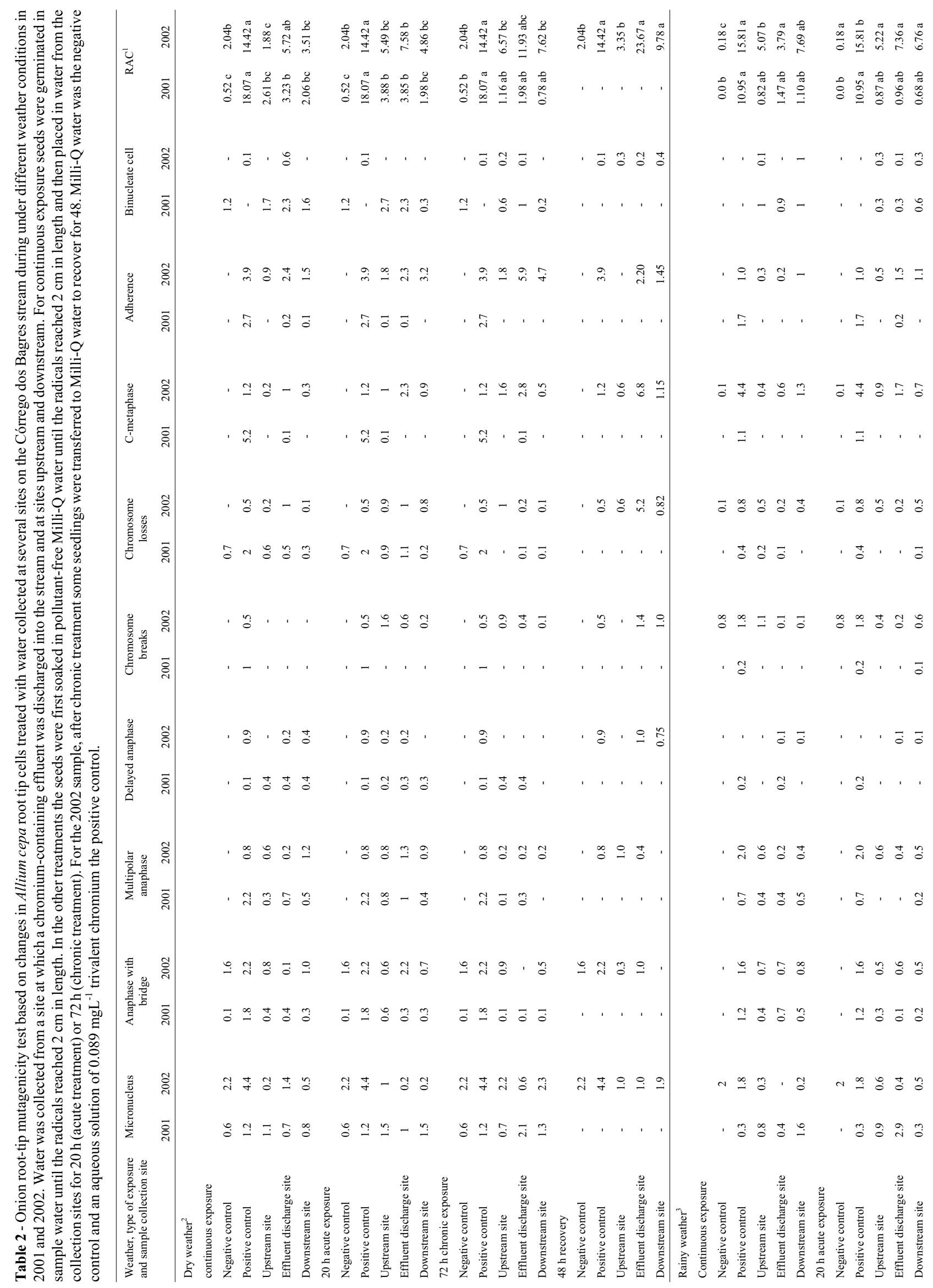




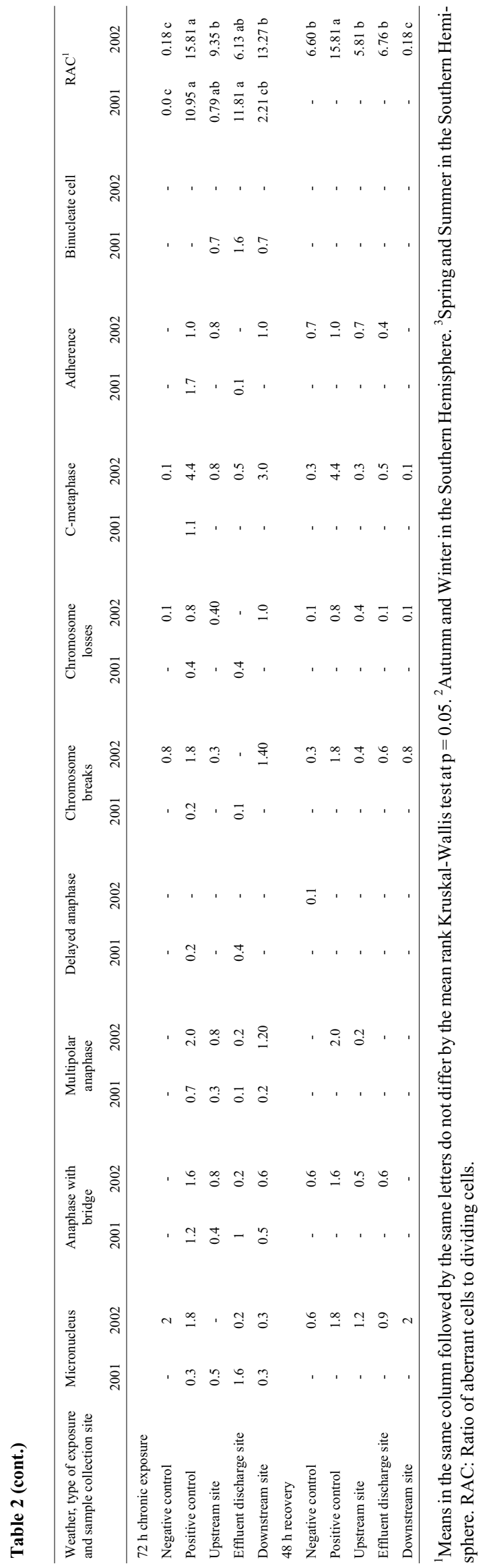

study, evidence of the action of chromium on the mitotic spindle was confirmed by the presence of c-metaphase cells.

We also observed that clastogenic and aneugenic frequencies were higher for water from the collection sites where total chromium concentration was highest (Table 3) and this supports the view of Sahi et al. (1998) and Matsu-

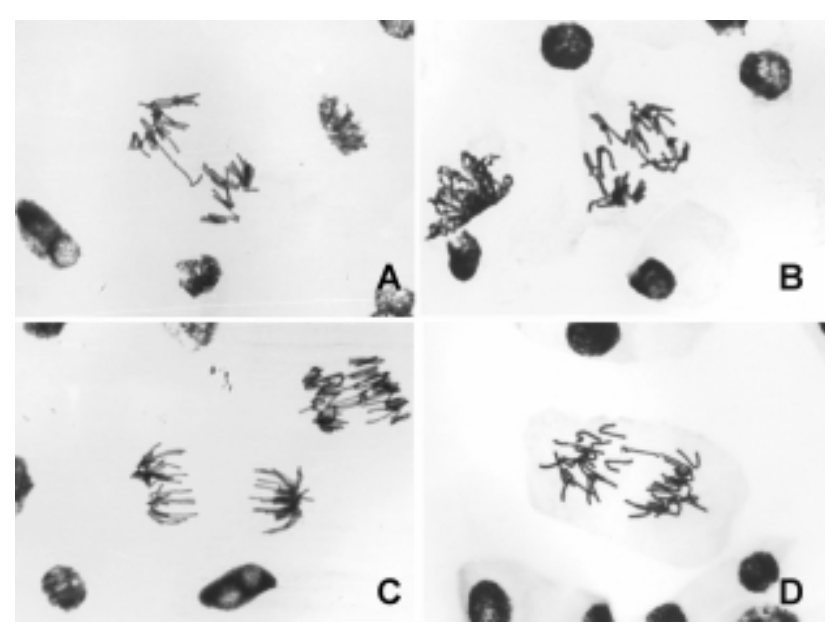

Figure 5 - Anaphase of the Allium cepa root tip cells treated with samples of water contaminated with chromium: A. anaphase with bridge; B and C. multipolar anaphases; D. anaphase with laggard chromosome and chromosome loss.

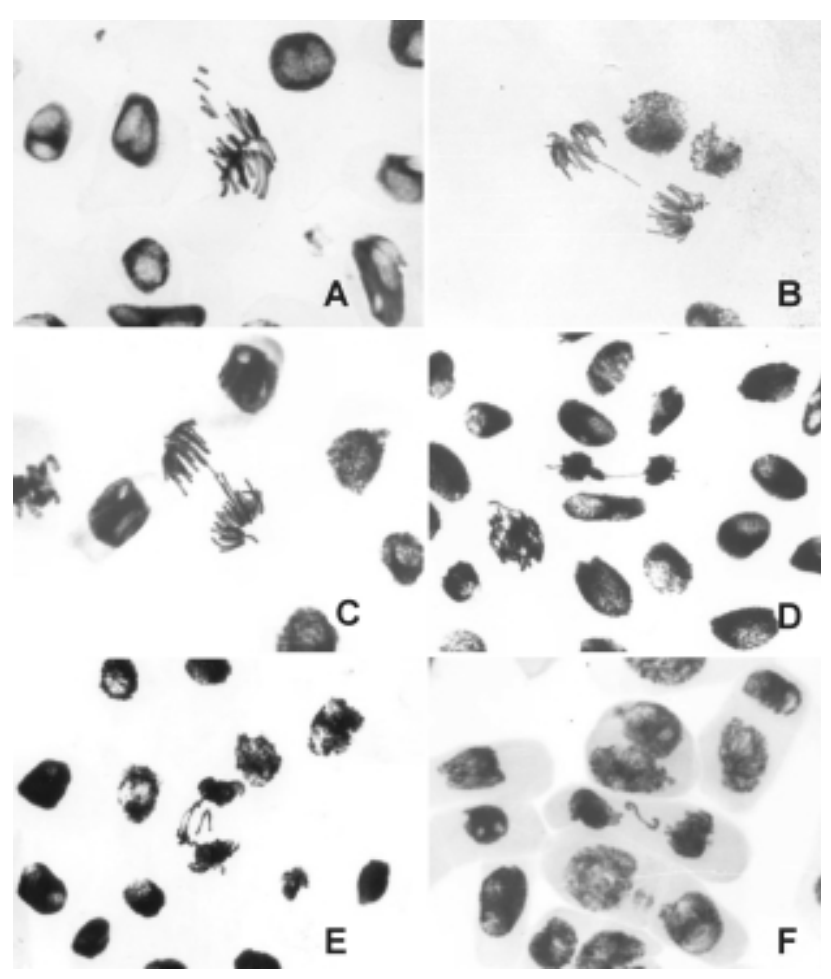

Figure 6 - Allium cepa root tip cells treated with water samples from the Bagres Stream: A. and B. cells with chromosome breaks showing chromosome fragments; C. anaphase with a bridge; D. telophase with a bridge; E. telophase with a bridge and with chromosomal loss; F. telophase with chromosomal loss. 


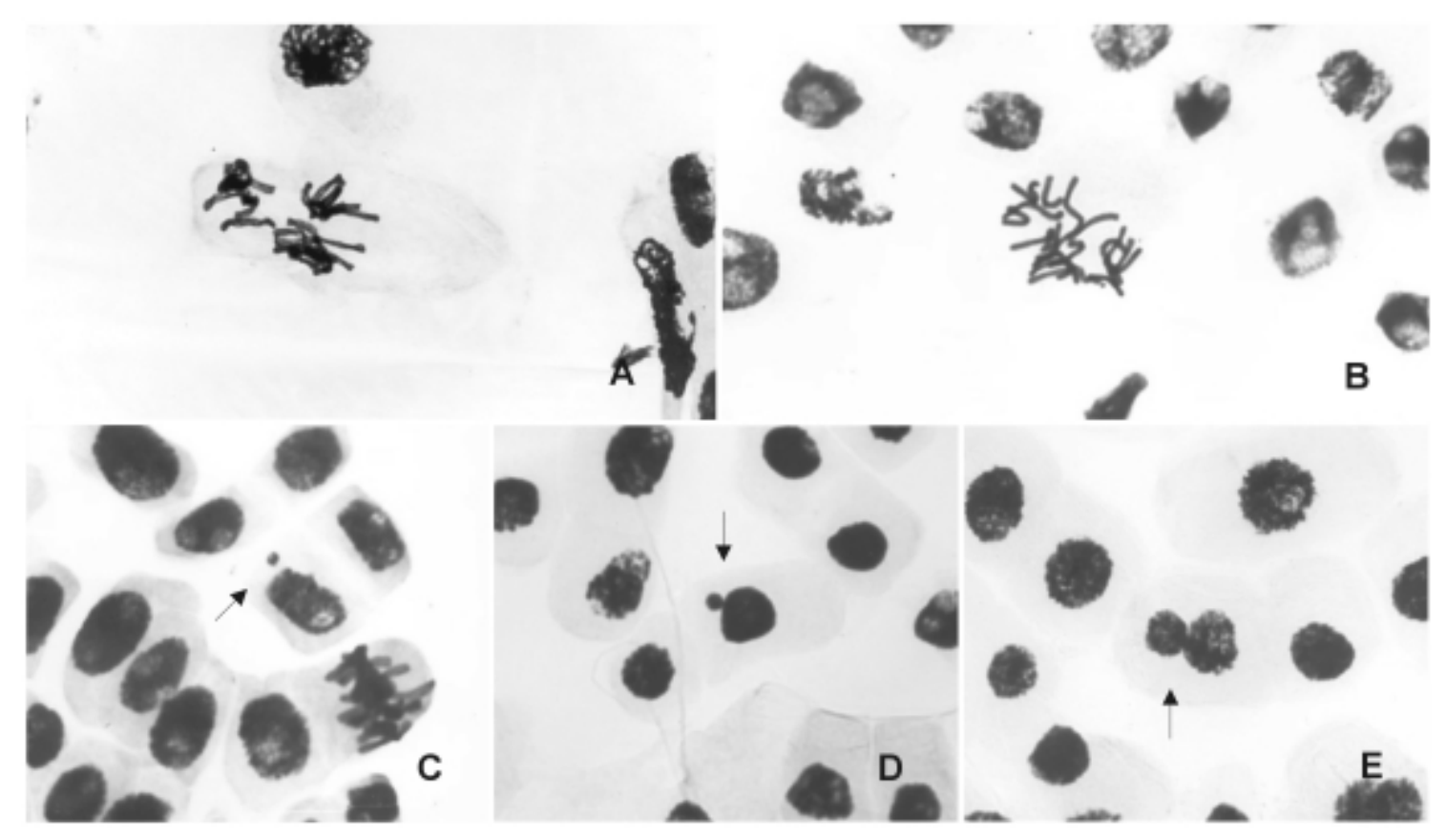

Figure 7 - Allium cepa root tip cells treated with water samples from the Bagres Stream contaminated with chromium residues: A. stick chromosome; B. C-metaphase; C. and D. cells with micronuclei; E. binucleate cell.

moto et al. (2004) who state that chromium has the potential to induce chromosome breaks (clastogenic effect) and losses (aneugenic effect) resulting in chromosome aberrations, micronucleus formation and binucleate cells.

The strongest mutagenic effect detected by us were recorded during the dry period from autumn and winter when the water flow is usually low, which results in a higher concentration of chromium. It is known that tannery effluents have the potential to damage the DNA of test organisms (Zhitkovich et al., 1996; O’Brien et al., 2001;
Matsumoto et al., 2003 and Matsumoto et al., 2004) and as such may compromise the quality of the water in the Corrego dos Bagres stream. Our data agree with that of Matsumoto et al. (2003) who used the comet assay and CHO-K1 cells to detect genotoxicicity in water from the Corrego dos Bagres stream collected during the winter dry period.

The legislation of the State of São Paulo establishes a maximum chromium concentration of $0.05 \mathrm{mgL}^{-1}$ for the emission of industrial effluents into rivers. In our study we found genotoxic effects on onion root-tip cells and erythro-

Table 3 - Chemical analysis of water collected at various sites on the Córrego dos Bagres stream during different seasons in 2001 and 2002.

\begin{tabular}{|c|c|c|c|c|c|c|c|c|c|c|c|c|}
\hline \multirow[b]{3}{*}{ Season and site (site code) } & \multicolumn{12}{|c|}{ Element $\left(\mathrm{mgL}^{-1}\right)$} \\
\hline & \multicolumn{2}{|c|}{$\mathrm{Pb}$} & \multicolumn{2}{|c|}{$\mathrm{Fe}$} & \multicolumn{2}{|c|}{$\mathrm{Cd}$} & \multicolumn{2}{|c|}{$\mathrm{Cr}$} & \multicolumn{2}{|c|}{$\mathrm{P}$} & \multicolumn{2}{|c|}{$\mathrm{Al}$} \\
\hline & 2001 & 2002 & 2001 & 2002 & 2001 & 2002 & 2001 & 2002 & 2001 & 2002 & 2001 & 2002 \\
\hline \multicolumn{13}{|l|}{ Summer (wet weather) } \\
\hline Upstream site & $<0.05$ & $<0.025$ & 0.21 & 0.36 & $<0.005$ & $<0.005$ & 0.05 & $<0.01$ & 1.5 & 0.32 & 0.33 & $<0.05$ \\
\hline Effluent discharge site & $<0.025$ & $<0.025$ & 0.8 & 0.28 & $<0.005$ & $<0.005$ & 0.38 & $<0.01$ & 2.20 & 0.24 & 0.43 & 0.07 \\
\hline Downstream site & $<0.025$ & $<0.025$ & 0.3 & 0.27 & $<0.005$ & $<0.005$ & 0.23 & $<0.01$ & 0.11 & 0.21 & 0.14 & 0.09 \\
\hline \multicolumn{13}{|l|}{ Autumn (dry weather) } \\
\hline Upstream site & $<0.025$ & $<0.012$ & 0.3 & 0.23 & $<0.005$ & $<0.003$ & $<0.01$ & $<0.005$ & 1.5 & $<0.1$ & 0.33 & 0.05 \\
\hline Effluent discharge site & $<0.025$ & $<0.012$ & 0.5 & 0.22 & $<0.005$ & $<0.003$ & 0.11 & $<0.005$ & 1.2 & 0.11 & 0.12 & 0.03 \\
\hline Downstream site & $<0.025$ & $<0.012$ & 0.3 & 0.27 & $<0.005$ & $<0.003$ & 0.05 & $<0.005$ & 1.1 & $<0.1$ & 0.07 & 0.1 \\
\hline \multicolumn{13}{|l|}{ Winter (dry weather) } \\
\hline Upstream site & $<0.025$ & $<0.02$ & 0.04 & 0.76 & $<0.005$ & $<0.003$ & $<0.01$ & 0.005 & 1.6 & $<0.1$ & $<0.05$ & 0.3 \\
\hline Effluent discharge site & $<0.025$ & $<0.02$ & 0.18 & 0.46 & $<0.005$ & $<0.003$ & 0.02 & 0.01 & 1.82 & 0.14 & 0.05 & 0.16 \\
\hline Downstream site & $<0.025$ & $<0.02$ & 0.15 & 0.19 & $<0.005$ & $<0.003$ & 0.02 & $<0.005$ & 1.22 & $<0.1$ & $<0.05$ & 0.25 \\
\hline \multicolumn{13}{|l|}{ Spring (wet weather) } \\
\hline Upstream site & $<0.025$ & $<0.02$ & 0.16 & 1.21 & $<0.005$ & $<0.003$ & $<0.01$ & $<0.005$ & $<0.1$ & $<0.1$ & 0.10 & 2.75 \\
\hline Effluent discharge site & $<0.025$ & $<0.02$ & 0.28 & 0.06 & $<0.005$ & $<0.003$ & 0.07 & $<0.005$ & 0.40 & 0.21 & 0.06 & 0.08 \\
\hline Downstream site & $<0.025$ & $<0.02$ & 0.19 & 1.29 & $<0.005$ & $<0.003$ & 0.03 & $<0.005$ & 0.22 & $<0.1$ & 0.22 & 3.48 \\
\hline
\end{tabular}




\begin{tabular}{|c|c|c|c|c|c|c|c|c|c|c|}
\hline \multirow[b]{3}{*}{ Season and site (site code) } & \multicolumn{10}{|c|}{ Element $\left(\mathrm{mgL}^{-1}\right)$} \\
\hline & \multicolumn{2}{|c|}{$\mathrm{Zn}$} & \multicolumn{2}{|c|}{$\mathrm{Cu}$} & \multicolumn{2}{|c|}{$\mathrm{Ba}$} & \multicolumn{2}{|c|}{ Co } & \multicolumn{2}{|c|}{$\mathrm{Ni}$} \\
\hline & 2001 & 2002 & 2001 & 2002 & 2001 & 2002 & 2001 & 2002 & 2001 & 2002 \\
\hline \multicolumn{11}{|l|}{ Summer (wet weather) } \\
\hline Upstream site & 0.11 & 0.01 & 0.01 & $<0.01$ & 0.04 & 0.05 & $<0.01$ & $<0.01$ & $<0.01$ & $<0.01$ \\
\hline Effluent discharge site & 0.04 & 0.01 & 0.01 & $<0.01$ & 0.05 & 0.05 & $<0.01$ & $<0.01$ & $<0.01$ & $<0.01$ \\
\hline Downstream site & 0.05 & 0.01 & $<0.01$ & $<0.01$ & 0.03 & 0.05 & $<0.01$ & $<0.01$ & $<0.01$ & $<0.01$ \\
\hline \multicolumn{11}{|l|}{ Autumn (dry weather) } \\
\hline Upstream site & 0.11 & $<0.005$ & 0.01 & $<0.005$ & 0.04 & 0.05 & $<0.01$ & $<0.005$ & $<0.01$ & $<0.005$ \\
\hline Effluent discharge site & 0.05 & 0.04 & $<0.01$ & $<0.005$ & 0.04 & 0.05 & $<0.01$ & $<0.005$ & $<0.01$ & $<0.005$ \\
\hline Downstream site & 0.01 & $<0.005$ & $<0.01$ & $<0.005$ & 0.04 & 0.05 & $<0.01$ & $<0.005$ & $<0.01$ & $<0.005$ \\
\hline \multicolumn{11}{|l|}{ Winter (dry weather) } \\
\hline Upstream site & 0.01 & $<0.005$ & $<0.01$ & $<0.005$ & 0.04 & 0.08 & $<0.01$ & $<0.005$ & 0.01 & $<0.005$ \\
\hline Effluent discharge site & 0.02 & $<0.005$ & $<0.01$ & $<0.005$ & 0.04 & 0.05 & $<0.01$ & $<0.005$ & 0.01 & $<0.005$ \\
\hline Downstream site & 0.01 & $<0.005$ & $<0.01$ & $<0.005$ & 0.05 & 0.01 & $<0.01$ & $<0.005$ & $<0.01$ & $<0.005$ \\
\hline \multicolumn{11}{|l|}{ Spring (wet weather) } \\
\hline Upstream site & 0.01 & 0.01 & $<0.01$ & 0.01 & 0.04 & 0.03 & $<0.01$ & $<0.005$ & $<0.01$ & $<0.005$ \\
\hline Effluent discharge site & 0.02 & 0.01 & $<0.01$ & 0.005 & 0.04 & 0.01 & $<0.01$ & $<0.005$ & 0.01 & 0.01 \\
\hline Downstream site & 0.01 & 0.01 & $<0.01$ & 0.01 & 0.06 & 0.01 & $<0.01$ & $<0.005$ & 0.01 & $<0.005$ \\
\hline
\end{tabular}

cytes from fish exposed to water taken from sites where the total chromium concentration was $0.01 \mathrm{mgL}^{-1}$, significantly less than the value established by the legislation currently in force in the state of São Paulo.

\section{Acknowledgment}

We are grateful to Cristiane Márcia Milleo for the assistance in preparation of the schematic figure.

\section{References}

Al-Sabti K (1986) Clastogenic effects of five carcinogenic chemicals on the cells of the common Cyprinus carpio L. Comp. Biochem Physiol 85:5-9.

Al-Sabti K (1994) Chromium-induced micronuclei in fish. J Appl Toxicol 14:333-336.

Al-Sabti K and Metcalfe C (1995) Fish micronuclei for assessing genotoxicity in water. Mutat Res 343:121-135.

Ayylon F and Garcia-Vazquez G (2000) Induction of micronuclei and other nuclear abnormalities in European minnow Phoxinus phoxinus and mollie Paecilia latipinna: An assessment of the fish micronucleus test. Mutat Res 467:177-186.

Beyersmann D, Block C and Malviya A (1994) Effects of cadmium on nuclear protein kinase C. Environ Health Perspect. Envirronmental Health Perspectives 102:177-180.

Bianchi V, Celotti L, Lanfreanchi G, Majone F, Marin G, Montaldi A, Sponza G, Tamino G, Venier P, Zantedeschi A and Levis AG (1983) Genetic effects of chromium compounds. Mutat Res 117:279-300.

Blasiak J and Kowalik J (2000) A comparison of the in vitro genotoxicity of tri- and hexavalent chromium. Mutat Res 469:135-145

Bombail V, Gordon E and Batty J (2001) Application of the comet and micronucleus assays to butterfish (Pholis gunnelus) erythrocytes from the Firth of Forth, Scotland. Chemosphere 44:283-392.

Carrasco KR, Tilbury KL and Mayers MS (1990) Assessment of the piscine micronuclei test as an in situ biological indicator of chemical contaminants effects. Can J Fish Aquat Sci 47:2123-2136.

Çavas T and Ergene-Gözükara S (2003) Micronuclei, nuclear lesions and interphase silver-stained nucleolar organizer regions (AgNORs) as cyto-genotoxicity indicators in Oreochromis niloticus exposed to textile mill effluent. Mutat Res 534:93-99.

CETESB - Companhia de Tecnologia de Saneamento Ambiental (1995) Controle de Poluição Ambiental. Legislação Estadual, São Paulo.

Claxton LD, Houk VS and Hugles TJ (1998) Genotoxicity of industrial wastes and effluens. Mutat Res 410:237-243.

Eiras JC (1990) Observations on erythrocytes abnormalities in fish. Bull Eur Ass Fish Pathol 10:64-67.

Franson MAH (1995) Standard Methods for the Examination of Water and Wastewater. Publication of American Public Health Association. 19th ed. Washington. 3120-Inductively Coupled Plasma Atomic, 3:33-39.

Garcia-Rodríguez MC, López-Santiago V and Altamirano-Lozano M (2001) Effect of chlorophyllin on chromium trioxide-induced micronuclei in polychromatic erythrocytes in mouse peripheral blood. Mutat Res 496:145-151.

Grover IS and Kaur S (1999) Genotoxicity of wastewater samples from sewage and industrial effluent detected by the Allium серa root anaphase aberration and micronucleus assays. Mutat Res 426:183-188.

Hose JE, Cross JN, Smith SG and Diehl D (1987) Elevated circulating erythrocyte micronuclei in fishes from contaminated sites of Southern California. Mar Environ Res 22:167-176.

Huber VS (1992) The genotoxicity of industrial wastes and effluents. Mutat Res 277:91-138.

Kong MS and MA TH (1999) Genotoxicity of contaminated soil and shallow well water detected by plant bioassays. Mutat Res 426:221-228.

Kosz-Vnenchak M and Rokosz K (1997) The "Comet" assay for detection of potential genotoxicity of polluted water. Folia boil 45:153-239. 
Lemos NG, Dias AL, Silva-Souza AT and Mantovani MS (2005) Evaluation of environmental waters using the comet assay in Tilapia rendalli. Environ Toxicol Pharmacol 19:197-201.

Leonard A and Lauwerys RR (1980) Carcinogenicity and mutagenicity of chromium. Mutat Res 76:227-239.

Majer BJ, Tscherko D, Paschke A, Wennrich R, Kundi M, Kandeler E and Knasmüller S (2002) Effects of heavy metal contamination of soils on micronucleus induction in Tradescantia and on microbial enzyme activities: A comparative investigation. Mutat Res 515:111-124.

Matsumoto ST (2003) Efeitos tóxicos e genotóxicos de metais pesados, especificamente do cromo trivalente e hexavalente. Tese de Doutorado, Universidade Estadual Paulista 'Júlio de Mesquita Filho', São José do Rio Preto.

Matsumoto ST and Marin-Morales MA (2004) Mutagenic potencial of the water of a river that receives tannery effluent using the Allium cepa test system. Cytologia 69:399-408.

Matsumoto ST, Mantovani MS, Mallaguti MI and Marin-Morales MA (2003) Investigation of the genotoxic potential of the waters of a river receiving tannery effluents by means of the in vitro comet assay. Cytologia 68:395-401.

Matsumoto ST, Mantovani MS, Rigonato J and Marin-Morales MA (2005) Evaluation of the genotoxic potential due to the action of an effluent contaminated with chromium, by the comet assay in cho-k1 cultures. Caryologia 58:40-46.

Metcalfe CD (1988) Induction of micronuclei and nuclear abnormalities in the erythrocytes of mudminnows and brow bullheads. Bull Environ Contam Toxicol 40:489-495.

Minissi S, Ciccotti E and Rizzoni M (1996) Micronucleus test in erythrocytes of Barbus plebejus (Teleostei, Pisces) from two natural environments: A bioassay for the in situ detection of mutagens in freshwater. Mutat Res 367:245-251.

Mitchelmore CL and Chipman JK (1998) DNA strand breakage in aquatic organisms and the potential value of the comet assay in environmental monitoring. Mutat Res 399:135-147.

Moraes DSL and Jordão BQ (2001) Evaluation of the genotoxic potential of municipal waste water discharged into the Paraguay river during periods of flood and drought. Environ toxicol 16:113-116.

Mount DR and Hockett JR (2000) Use of toxicity identification evaluation methods to characterize, identify, and confirm hexavalent chromium toxicity in an industrial effluent. Water Res 34:1379-1385.
O'Brien T, Xu J and Patierno SR (2001) Effects of glutathione on chromium-induced DNA crosslinking and DNA polymerase arrest. Mol Cell Biochem 222:173-182.

Pachecco M and Santos MA (1998) Induction of liver EIROD and erythrocytic nuclear abnormalities by cyclophosphamide and PAHs in Anguilla anguilla L. Ecotoxicol Environ Saf 40:71-76.

Patra M and Sharma A (2002) Relative efficacy of Allium cepa and Allium sativum in anaphase-telophase test screening metal genotoxicity. Biologia 57:409-414.

Rank J and Nielsen MH (1998) Genotoxicity testing of wastewater sludge using the Allium cepa anaphase-telophase chromosome aberration assay. Mutat Res 418:113-119.

Sahi AN, Singh SK, Sem PK and Singh RN (1998) Gytogenetic response of hexavalent chromium-induced somatic cell abnormalities in Allium cepa Cytobios 96:71-79.

Singh J, Bridgewater LC and Patierno SR (1998) Differential sensitivity of chromium-mediated DNA interstrand crosslinks and DNA-protein crosslinks to disruption by alkali and EDTA. Toxicol Sci 45:72-76.

Stohs SJ and Bagchi D (1995) Oxidative mechanisms in the toxicity of metal ions. Free Radic Biol Med 18:321-336.

Sudhakar D, Panda KK and Panda BB (1998) Biomonitoring of low levels of mercurial derivatives in water and soil by Allium micronucleus assay. Mutat Res 203:11-23.

Sudhakar R, Ninge-Gowda KN and Venu G (2001) Mitotic abnormalities induced by silk dyeing industry effluents in the cells of Allium cepa. Cytologia 66:235-239.

Sugiyama M (1992) Role of physiological antioxidants in chromium (VI)-induced cellular injury. Free Radic Biol Med 12:397-407.

Tice RR, Agurell E, Anderson D, Burlinson B, Hartmann A, Kobayashi H, Miyamae Y, Rojas E, Ryu JC and Sasaki YF (2000) Single cell gel/Comet assay: Guidelines for in vitro and in vivo genetic toxicology testing. Environ Mol Mutag $35: 206-221$.

Von Burg R and Liu D (1993) Chromium and hexavalent chromium. J Appl Toxicol 13:225-230.

White PA and Rasmussen (1998) The genotoxic hazards of domestic wastes in surface waters. Mutat Res 410:223-236.

Zhitkovich A, Voitkun V and Costa M (1996) Formation of the amino acid-DNA complexes by hexavalent and trivalent chromium in vitro: Importance of trivalent chromium and the phosphate group. Biochemistry 35:7275-7282.

Associate Editor: Catarina S. Takahashi 